\title{
Place sustainability at the heart of the quality agenda
}

\author{
Justyn M Thomas, Paul A Cosford
}

If the guiding ethos of health systems throughout the world were 'live for the day,' two pillars of quality would suffice. Effective use of finite resources, measured by evidence-based outcomes relating to patient health, safety and experience is, without question, the predominant pillar. $^{1-5}$ Next to effectiveness is its close ally, efficiency. ${ }^{3}$ Efficient use of resources minimises waste, thus maximising the quantity of high-quality healthcare and, in combination, with effectiveness provides the critical measure of productivity.

\section{RISKS OF LIVING FOR THE DAY}

Living for the day, however, is a high-risk mindset, and if a health system is also to prosper 'tomorrow,' a sensible precaution must be to embrace a further pillar of quality: sustainability. Put simply, this concerns the use of resources in a way to build, rather than undermine, operative resilience for the future delivery of high-quality healthcare. ${ }^{6}$

Risk to quality, due to misuse of resources, arises both externally and internally. External risk results from using resources in a way that destabilises the foundations of the interconnected economic, societal or environmental world in which the health system operates. Internal risk results from using resources in a way that outstrips supply, again compromising function. Both, ultimately, relate to economic viability, and both are usually linked. This is certainly the case for carbon reduction.

The UK offers an excellent example of how carbon reduction can be a surprisingly divisive issue. It offers a case study that demonstrates the challenges, as well as the opportunities, as one country has worked to cope with both the economic and political ramifications of carbon reduction. In particular, much focus has fallen on the 'external' risk of greenhouse gas emissions to global health ${ }^{78}$ and economic stability. ${ }^{9}$

NHS East of England, Fulbourn, Cambridge, UK

Correspondence to Dr Justyn Thomas, NHS East of England, Victoria House, Capital Park, Fulbourn,

Cambridge CB21 5XB, UK; justyn.m.thomas@gmail.com
That the UK's National Health Service (NHS), as Europe's largest public sector carbon emitter, might contribute to this provides, for many, a moral imperative to reduce 'in-house' emissions. However, just as sustainability neither starts nor stops with carbon, so the compelling economic need to reduce carbon emissions neither begins nor ends with climate change.

While healthcare activity (equipment, lighting, heating, cooling, construction, transport and delivery, and so on) is largely powered by fossil fuels, wider 'internal' system inefficiencies can be highlighted by measuring the carbon waste or footprint of healthcare pathways. This inverse metric of quality can then be used as a catalyst to drive the development of a leaner, more productive and economically viable, health system. Beyond simply ensuring that money is not wasted that could otherwise be directed to patient care, this process should be integral to all aspects of healthcare improvement, the lesson being that an advance in quality can only be considered as such, if it proves sustainable.

A further economic pressure for health systems arises from emerging carbon levies. In the UK, for example, the government has introduced a legally binding Carbon Reduction Commitment. This gives a theoretical cost of $£ 12$ per tonne of carbon. Each hospital or organisation is given a cap, and if they exceed this, they will need to pay for the carbon they emit. At current levels, the NHS in England could end up paying an additional $£ 200$ million unless it reduces its emissions considerably.

\section{ONE COUNTRY'S FIRST STEPS: THE NHS SUSTAINABLE DEVELOPMENT UNIT}

These risks have prompted the health service in England to found the NHS Sustainable Development Unit. ${ }^{10}$ Learning from national and international best practice, its work and policies relate not only to reducing waste in existing care pathways but also to improving efficiency by transforming how healthcare is provided. Examples of this are prioritisation of disease prevention, improved integration of primary and secondary care with rewards for outcomes over activity, smart procurement and better use of information and communication technology-principles that are near-universally to the benefit, not cost, of quality, and that will resonate across the international healthcare community.

That sustainable practice goes hand in hand with economic viability and health system improvement is all too often overlooked, leaving the possible impression that the sustainability agenda is separate from that of delivering quality. This may, in part, explain the omission of sustainability from most definitions of quality, including that most recently worked to by the NHS, ${ }^{1}$ as well as the variable pattern of initiatives to reduce health-system carbon emissions both within the UK and internationally. The publication of two reports earlier this year will go some way to changing perceptions. First is the UK's Royal College of Physician's report 'Leading for quality-the foundation for healthcare over the next decade,' that recommends placing sustainability at the heart of health service decision-making. ${ }^{11}$ Second is the NHS Carbon Reduction Strategy Update, ${ }^{12}$ which for the first time attaches tangible financial savings to NHS carbon-saving measures. Presently, most of this analysis is restricted to waste in terms of the physical estate but still identifies savings in excess of $£ 180$ million per year and will critically act as the forerunner of inefficiency analysis across whole care pathways-an approach that promises to deliver far larger savings and can be applied to all health systems

There is no escaping the fact that quality-focused healthcare policy everywhere must be built on viable economic grounds. However, the issue is not whether health systems throughout the world community can afford to embrace sustainability but whether they can afford not to.

PAC also works for the Department of Health as director of public health and JMT is clinical advisor. This is an independent article written by PAC and JMT, and the views expressed in this article are not necessarily those of the Department of Health.

\section{Competing interests None.}

Provenance and peer review Commissioned; externally peer reviewed.

Qual Saf Health Care 2010;19:260-261. doi:10.1136/qshc.2010.044123

\section{REFERENCES}

1. Department of Health. NHS next stage review final report. High Quality Healthcare for All, 2008. 
http://www.dh.gov.uk/prod_consum_dh/groups/ dh_digitalassets/@dh/@en/documents/digitalasset/ dh 085828.pdf (accessed 21 May 2010).

2. Raleigh VS, Foot C. Getting the measure of quality. The King's Fund. London: The Stationery Office, 2010. http://www.KingsFund.org.uk/research/ publications/quality_measures.html (accessed 21 May 2010).

3. Institute of Medicine. Crossing the quality chasm: a new health system for the 21st century. Washington, DC: National Academy Press, 2001.

4. Arah $\mathbf{0 A}$, Westert GP, Hurst J, et al. A conceptual framework for the $\mathrm{OECD}$ health care quality indicators project. Int $\mathrm{J}$ Qual Health Care 2006;18(Suppl 1):s5-13.

5. Kelley J, Hurst J. Health Care Quality Indicators Project Conceptual Framework Paper. Organisation for Economic Co-operation and Development's Health Working Papers No. 23, 2006 http://www.oecd.org/ dataoecd/1/36/36262363.pdf laccessed 21 May 2010).

6. United Nations General Assembly. Report of the World Commission on Environment and Development: Our Common Future. Transmitted to the General Assembly as an Annex to document A/42/427 Development and International Co-operation: Environment, 1987. http://www.un-documents.net/ ocf-02.htm (accessed 21 May 2010).

7. McMichael AJ, Nyong A, Corvalan C, et al. Global environmental change and health: impacts, inequlaities, and the health sector. $B M J$ 2008;336:191-4.

8. Costello A, Abbas M, Allen A, et al. Managing the health effects of climate change: Lancet and
University College London Institute for Global Health Commission. Lancet 2009;373:1693-733.

9. Stern review: the economics of climate change. HM Treasury, 2006. http://www.hmtreasury.gov.uk/ sternreview_index.htm (accessed 21 May 2010).

10. NHS Carbon Reduction Strategy for England: Saving Carbon, Improving Health. NHS Sustainable Development Unit. http://www.sdu.nhs.uk/page.php? area $\mathrm{id}=2$.

11. The Royal College of Physicians. (2010). Leading for Quality - the Foundation for Healthcare over the Next Decade. http://www.rcplondon.ac.uk/Aboutthe-college/mission/Documents/RCP-Leading-ForQuality.pdf (accessed 21 May 2010).

12. NHS Carbon Reduction Strategy update. NHS Sustainable Development Unit. http://www.sdu.nhs. uk/page.php?page id=160 (accessed 21 May 2010) 